spaces, it was the stable sacramentality of crucifixes, frescoes, and altarpieces that consecrated confraternal oratories. Lay brothers aimed to capture that charism through patronage of all or some of this art and architecture, as we see in Rome (Kira Maye Albinsky), Rouen (Caroline Blondeau-Morizot), Florence (Douglas N. Dow), Palermo (Danielle Carrabino), and Seville (Ellen Alexandra Dooley).

Any collection dedicated to exploring a new scholarly turn runs the risk of incoherence as the authors go, in Stephen Leacock's memorable phrase, "madly off in all directions." Editor Diana Bullen Presciutti has worked expertly to draw the authors and articles together, and to encourage a formal discipline that underscores their arguments and connections. A common bibliography incorporating archival and secondary sources makes this a valuable guide to the status quaestionis, while an extraordinary collection of well over one hundred maps and illustrations, many of them in colour, underscores the visual and sensory themes that connect the various pieces. Above all, they animate the central argument that tracing space, place, and motion are as important as measuring politics, kinship, and ritual when we aim to demonstrate the critical role that confraternities played in the social, physical, sensory, and psychic worlds of the early modern world.

NICHOLAS TERPSTRA

University of Toronto

\title{
Provan, Iain.
}

\section{The Reformation and the Right Reading of Scripture.}

Waco, TX: Baylor University Press, 2017. Pp. 730. ISBN 978-1-4813-0608-9 (hardcover) US\$49.95.

In the Reformation, the inspiration and authority of the Bible-its perspicuity, efficacy, and sufficiency-came to the fore. For the present generation that has lost its confidence in the Bible, Iain Provan's book has recaptured and recovered the internal structure and logic of the Reformation hermeneutic, with its emphasis on the literal sense. Strategically, Provan engages with four contemporary "ways" of reading Scripture that he finds somewhat deficient. Provan's ways are as follows (13-21): first, "Historical Criticism" (e.g., James 
Barr); second, "Postmodern Reading" (e.g., John Caputo, the emergent church); third, "The Chicago Constituency" (defined by adherence to The Chicago Statement on Biblical Hermeneutics); fourth, "Counter-Reformational Protestantism" (e.g., Hans Boersma). This book is his attempt to chart a fifth way forward, namely, the "literal sense" of the Scripture.

Readers can reap from Provan's tome benefits or thoughts that might fructify discussions among Reformation circles on what is called "the right reading of scripture." Provan offers an extensive knowledge of the history of biblical interpretation, which is beneficial to both theologians and biblical scholars. In chapters 14 and 16, one finds an audacious critique of "third way Chicago" readers of the book, which Provan considers to be a "warfare model" of the relationship between Christianity and science. This model, he argues, has resulted in exegetical problems in the interpretation of some biblical texts (notably Gen 1-11) and creates a "credibility gap" in the public audience between faith and science. While this may sound reasonable, readers would profit from some concrete examples of how the third-way Chicago readers might help resolve the credibility gap, rather than just a brief comment on it.

One of the most intriguing parts of the book is Provan's interaction with Hans Boersma, who proposes a Counter-Reformation hermeneutic, which he calls a "sacramental ontology," as a way of viewing God's relationship with the world-in which creation participates through Christ in God (416-23). Provan lists several difficulties he has with Boersma's sacramental hermeneutic, one being any "spiritual reading" that deviates from the literal sense of the text, which "deprives Scripture of its ability truly to function authoritatively. It is exactly what destroys our capacity to perceive when the teaching of Plato or anyone else conflicts with scriptural teaching" (418). With James Smith, Provan accentuates the priority of a biblically-informed ontology and its uniqueness vis-à-vis the Platonic ontology. What is wrong with this ontology, Provan claims, is not so much that it tries to return to Scripture, but that it does not return "far enough" (419). In his words: "The end of criticism is to cast light, indeed, on the way that Scripture does this sufficiently as it is read literally and historically in line with Reformation thinking [...] a truly literal and historical reading is already a canonical and spiritual reading [...] The spiritual depths of Scripture are evident to all those who engage with growing understanding [with the help of the Holy Spirit] in its 'seriously liberal interpretations'” (63839). What Provan says here echoes Luther, who insisted that the Bible, unlike 
all other books, must be read as one for which prayer and the Holy Spirit are required in order to apprehend the literal interpretation, leading its readers to a confession of the word as the Word.

The Bible has come under the attack of the Enlightened modernity: it is read like any other text and subjected to scrutiny under the historicalcritical method derived from sciences and philosophy. On the one hand, Provan is keenly cognizant of the modern and post-modern critical methods, their promise and problems; on the other hand, he places much value on the church's pre-critical appropriation of the Bible. He underscores the Protestant hermeneutics of the sixteenth century, and the need for the present generation to be in continuity with them. In so doing he has succeeded in repositioning the Bible as the beginning, middle, and end of Christian faith and practice.

DENNIS NGIEN

Tyndale University College \& Seminary

\section{Raphael, Renée.}

\section{Reading Galileo: Scribal Technologies and the Two New Sciences.}

Baltimore: Johns Hopkins University Press, 2017. Pp. xi, 265. ISBN 978-1-42142177-3 (hardcover) \$54.95.

The Discourses on Two New Sciences was Galileo's last and most important scientific work. In it, among other things, he laid the foundations of two entirely new mathematical sciences. The first was the new science of the strength of materials, which he founded on the principles of mechanics and on the power of the supposed interparticulate void. The second-and the more important for the history of science-was the new mathematical science of motion, the culmination for him of fifty years of study and careful experiments. Here he laid out in axiomatic form the mathematical principles of uniform and accelerated motions, notably that in the natural fall of heavy bodies speed increases as time and that distances in successive equal times are as the series of odd numbers. The ultimate legacy of his work was the ouster of the bookish methods of scholastic natural philosophy and the rise of mathematical and experimental science. 